Jelena Salkovska, D. Sc., Assistant professor, Assistant professor of Faculty of Business, Management and Economics of University of Latvia,

Riga, Latvia

Anda Batraga, D. Sc., Professor, Professor of Faculty of Business, Management and Economics of University of Latvia;

Riga, Latvia

Liga Braslina, Researcher, Researcher of Scientific Institute of Economics, and Management of University of Latvia,

Riga, Latvia

\title{
CONSUMER BEHAVIOUR IN INNOVATIVE PRODUCTS PURCHASING PROCESS
}

Nowadays, innovation has become one of the most important preconditions for a successful business and, consequently, also for successful development of national economy and economics. The aim of the article is to assess the factors influencing the behaviour of Latvian consumers, purchasing innovative packaged food and non-alcoholic beverages, based on theoretical aspects of consumer behaviour in innovative products purchasing process. As the result of the research, proposals were made for Latvian companies for improving innovative products marketing activities, commercialization and promotion of innovative products. A structured data collection was carried out using questionnaires, which resulted in a survey of 458 respondents from all over Latvia. The surveyed respondents by gender were $59.65 \%$ females and $40.35 \%$ males. The respondents were divided into 6 age groups, starting from 18 years old. The authors chose not to interrogate young people under the age of 18 , assuming that they had no personal and independent income to purchase packaged food and non-alcoholic beverages. According to the findings, the authors allocated the main characteristics of respondents by their adaptation to innovative products: "innovators", "followers" and "slowly adapting". Under this research, the authors used the correlation analysis to estimate the relations between the level of income, age and gender of respondents and the type of consumer in relation to innovations was revealed. The higher income level is, the higher is the proportion of people who perceive themselves as innovators or quickly adapting in the field of packaged food and non-alcoholic beverages, and the lower income level is, the greater is the proportion of slowly adapting people. In general, the specificity of packaged food and nonalcoholic beverages is explained with the fact that consumers adapt to innovative products of this category much faster because it does not require large investments.

Keywords: consumer behaviour, innovative product, innovative product purchasing process, adaptation to a new product, product innovation.

Introduction. Nowadays, entrepreneurship and innovation are the key drivers of national economy, which, in combination with knowledge and technology, form innovation economy. The aim of innovation economy is to stimulate a higher productivity by developing innovations. According to the study project by 
the US National Academy of Sciences, "Changes in Production Perspectives 2020", innovation is one of the key factors affecting production in 2020. [17].

In response to the rapidly changing structure of consumer demand and the current dynamic lifestyle, companies need to promote innovations, based on new technologies and structures. Company's innovations relate to products, services, operations, processes and people. Schumpeter J.A. stressed that companies need to promote innovations in order to restore the value of company's assets. [25, p. 56-109]. Innovations have a key role in the process of value creation and the achievement of competitive advantages. Zahra S.A. and Covin J.G. emphasize that innovations are considered to be the blood of corporative survival and growth. [30, p. 183-211].

Consequently, the importance of innovations both at microeconomic and macroeconomic level actualizes in current market situation the necessity of marketing information on consumer behavior and its influencing factors in innovative products purchasing process. The study of consumer behavior and its influencing factors has an important role in commercialization of innovative products and their promotion, in order to enable the company to create innovations and offer them to the consumers at an appropriate and affordable price.

Analysis of recent researches and publications. The impact of innovations on national economy and economic growth, as well as the problems of innovation economy development were researched in the studies of such scientists as: Schumpeter J.A. [25] Antonelli C. [2], Ahistrom D. [1], Pfeiffer F. and Brade J. [20], Rodriguez A., Dahlman C., Salmi J. [23] et al. They emphasize the role of innovations in improving the competitiveness of a country and promotion of economic growth.

The role of innovations in company development was studied in the works of the following scientists: Zahra S.A., Covin J.G. [30], Bessant J. [5], Damanpour F. [8], Peter T., Waterman R. [13], Thompson A. [26], Dosi G. [9], Kimberly R. [14], Van de Ven A. [29], Nonaka I. [16], Brawn S., Eisenhardt K. [6], Plessis D. [21], Eisenhardt K., Tabrizi N. [12], Axtell M. [3] In these studies the emphasis was placed on innovation development influencing actors, including the dependence of innovation process on the resources and strategies of a company.

Scientists Batraga A., Salkovska J., Braslina L., Legzdina A., Kalkis H. conducted a study on identification and process of the sources of information on conceptual ideas of innovation, as well as approbation of thee sources and methods of innovation model InnoMatrix in food industry. [4]. The conclusions of InnoMatrix approbation in food industry indicate that the model is applicable to innovation analysis and requires further research.

Various theoretical aspects of innovations at company level and national level, as well as practical aspects of innovation in the Baltic States were researched in the study of Dubra I. [10]. In the studies of Dunska M. and Olevskis G. innovations are associated with the development of intellectual capital and science-intensive business. [18; 19].

Unsolved issues as part of the problem. At company level, product innovations, process innovations, organizational innovations and marketing innovations are currently being considered, i.e. introduction of a new product or service, new process, new marketing methods or new organizational methods to business. The creation and application of product, process, organizational and marketing innovations serve to sustainable economic growth and development in a modern socio-economic environment. [11, p. 264-279]. Innovations are developed mostly in innovative companies. Rradical innovations that relate to products and processes resulting from the development of knowledge and incremental innovations, appeared as the result of a knowledge development process, and additional (incremental) innovations, related to the continuous process of technical improvement, are distinguished. [27, p. 120-159].

Marketing innovations as one of the types of company-level innovations were researched in the studies of the following scientists: Praude V., Salkovska J. [22], Batraga A., Salkovska J., Zilina B. [24]. The 
emphasis was put on the necessity of use of digital technologies in innovative marketing, taking into account society digitalization processes.

Tirol J. [28] emphasizes product innovations, i.e. new types of goods and services that are introduced to the market and process innovations that focus on reducing the cost of already produced goods and services.

In this article, the authors focus on product innovations. Product innovations include new or substantially improved products or services. Product innovation means significant improvements in technical specification, various components and materials, existing software, user-friendliness or other functional properties. In each category of products, innovation has specific manifestations. Within this article, the authors focused their attention on innovative packaged food and non-alcoholic beverage products.

The food industry branches need both product and process innovations; however, from the point of view of consumer value, product innovations are much more convincing and therefore often have a higher market significance used by the company. Consumers expect innovations, which are reflected in the new trends that are currently appearing in consumer markets. In particular, $63 \%$ of consumers are waiting for new products, $56 \%$ would like to switch to a new brand and $49 \%$ would inform people about recently purchased products [15]. Therefore, the key problem is the search for food innovations so that the food industry could continue to grow. The solution that Nielsen report [15] suggests is that one should focus on the consumers whose behavior ultimately leads to innovations, rather than relying on the sellers that due to the past results and practices are not able to decide which innovation is genuine and which is not. Only consumers' desires and aspirations, as well as their behavior in purchasing process can reveal and approve an innovation. Therefore, in order to introduce innovations through consumers' unsatisfied demands, food manufacturers should more closely follow consumers' consumption trends.

According to XTC World Innovation [31], more than half of the food products, manufactured in 2014, aimed at the need to enjoy. The second important objective was to make the products healthier and, thirdly, to make them more comfortable. Consumer expectations related to physical and ethical issues were the least important to the food manufacturers. Food manufacturers are mainly interested in making products more diverse in terms of sense, smarter, easier to use, more natural and curing, while the least important are those features related to cosmetics, solidarity, ecological and natural plant trends. No doubt, one should remember that in different geographic locations and for different product groups different trends prevail.

Due to strong global competition, it is becoming increasingly difficult to offer differentiated food products that are better than the existing ones. This is another argument why not sellers, but consumers and their propensity should determine the types and nature of food innovations.

Aims of the article. The aim of the article is to assess the factors influencing the behavior of Latvian consumers, purchasing innovative packaged food and non-alcoholic beverages, based on theoretical aspects of consumer behavior in innovative products purchasing process.

Basic material. The consumer can pass the purchasing process stages quickly or slowly, but it depends on many factors, such as consumer behavior, purchasing situations and the product itself. The purchase of new products is different from the purchase of ordinary products, as it has several peculiarities. One of the most important features is consumers' adaptation to the new product.

Adaptation process is the term for consumer behavior, starting from the first-time information on the product up to complete recognition of the product. Adaptation process consists of 5 stages:

1. Preliminary knowledge - the consumer comes to know about the product, but lacks complete information;

2. Interest - the consumer is interested in getting information about the new product;

3. Assessment - the consumer decides whether it is worthwhile to purchase the novelty; 
4. Testing - the consumer buys the new product and compares the effect of its usage with the price and with other similar or analogous products;

5. Adaptation - the consumer decides to continue purchasing and using the new product. [22, p. 224]

Of course, the length of time the consumer will be in the particular stages of adaptation process and what stage he or she will achieve would depend on both the type of product and the consumer's personal qualities. Under the same conditions (belonging to the same social strata, income level, etc.) there will always be people who will adapt to new products faster than others.

There are different consumer groups observed:

- Innovators - people who like to take risks and try out new ideas, products, etc.;

- Quickly adapting - people who are public opinion leaders in their circles, adapt to innovations rather quickly, but nevertheless cautiously;

- Prudent - cautious people who usually carefully assess and choose new products; they usually adapt to public opinion leaders, but this happens faster than for the others;

- Late adapting - these are skeptical who adapt only when most of people have already bought the product;

- Slowly adapting - people who do not mind change and choose to try innovation only if it does not contradict with their traditions.

People are different, and so is their willingness to buy new goods. Each product group has its own "innovators", "followers" and "slowly adapting".

Researches shows that, innovators make about $2.5 \%$, rapidly adapting - about $13.5 \%$, prudent - $34 \%$, late adapting - $34 \%$, but slowly adapting - $16 \%$ of all consumers. Also, young people, people with a high social status, people who are not financially endangered and those who are mentally developed and use different sources of information adapt to novelties rather quickly. [22, p. 225]

Personal attitude, i.e., the effect, appearing from various people expressions on a particular product., is also important in innovation perception process. Personal attitude has an important role in the various aforementioned consumer groups, for example, personal attitude has a greater role for late adopting people than for prudent people, which means that prudent people need fewer reviews from others about a particular product than late adapting people.

At the same time, however, it is also observed that adaptation is influenced not only by psychological factors or personal opinions, but also by the product characteristics. For example, there are novelties become popular and liked by consumers in a very short time while there are also novelties that require a long period of time (one year or more) to become popular. General product characteristics that have a positive effect on adaptation are the following:

- Comparative advantages - the consumer should perceive the new product with a confidence and belief in its benefits compared to other similar products;

- Compatibility - the product must meet consumers' assessment and experience, taking into account personal and psychological factors;

- Degree of complexity - relative understanding of the nature of the product and the principles of its usage;

- Demonstrativeness - opportunity to get acquainted with the product and the results of its usage (exhibitions, etc.);

- Approbation opportunity - possibility to try the product without paying the full price.

In March-April 2018, a survey of Latvian residents was conducted under the authors' guidance In order to evaluate the behavior of Latvian consumers, incl. adaptation influencing factors in purchasing innovative packaged food and non-alcoholic beverages. A structured data collection was carried out using questionnaires, which resulted in a survey of 458 respondents from all over Latvia. The surveyed respondents by gender were $59.65 \%$ females and $40.35 \%$ males. The respondents were divided into 6 
age groups, starting from 18 years old. The authors chose not to interrogate young people under the age of 18 , assuming that they had no personal and independent income to purchase packaged food and nonalcoholic beverages. In the age group 18 to 27 years old, $21.48 \%$ of interrogated people responded, while the percentage of responded people of those aged $28-37$ years old was $15.62 \%$, of those aged $38-47$ $16.49 \%$, aged $48-57-14.75$, aged $58-67-13.45 \%$, and aged above 67 years $-18.22 \%$. By regional breakdown, $48.91 \%$ of the respondents were from Riga or Pieriga, $17.61 \%$ - from Latgale, $12.17 \%$ - from Vidzeme, $11.09 \%$ - from Kurzeme, and $10.22 \%$ from Zemgale. The distribution of respondents by income level was as follows: $21.35 \%$ of the respondents receive wage before the minimum, $15.47 \%$ receive the minimum wage, $25.05 \%$ receive the wage between the minimum and average, $20.48 \%$ receive average wage, $16.34 \%$ receive the wage above average and $1.31 \%$ of all respondents receive a high wage. Working people make the largest portion of people surveyed among, accounting for $54.97 \%$ of the responses. $19.43 \%$ of the surveys were filled by pensioners, $7.73 \%$ - by working students, $6.62 \%$ - by students, $4.64 \%$ - by working pensioners, while $2.65 \%$ of respondents were on maternity leave, $2.21 \%$ were unemployed and $1.77 \%$ - were classified as the others. It can be considered that most of respondents are earning, which means that they have their own income that can be spent on innovative packaged food and non-alcoholic beverages. In general, the distribution of respondents corresponds to the distribution which is peculiar for Latvia, which confirms the representativeness of the survey conducted. [7].

According to the results of the survey, it was found that, depending on adaptation to the new product, the largest number of all respondents are prudent - 36.68\%, the next large group are quickly adapting $29.69 \%$, following by slowly adapting $-12.45 \%$ and innovators $-11.14 \%$, while late adapting are the least numerous - $10.04 \%$ of all respondents. This breakdown may vary for different products and services, depending on their complexity, cost, and duration of usage. As food is not a big investment and does not require much knowledge or prior research, people adapt much faster. It also clearly shows whether a person wishes to try new food products at all, or is completely satisfied with the products he or she has, so there is no need to adapt (see Figure 1).

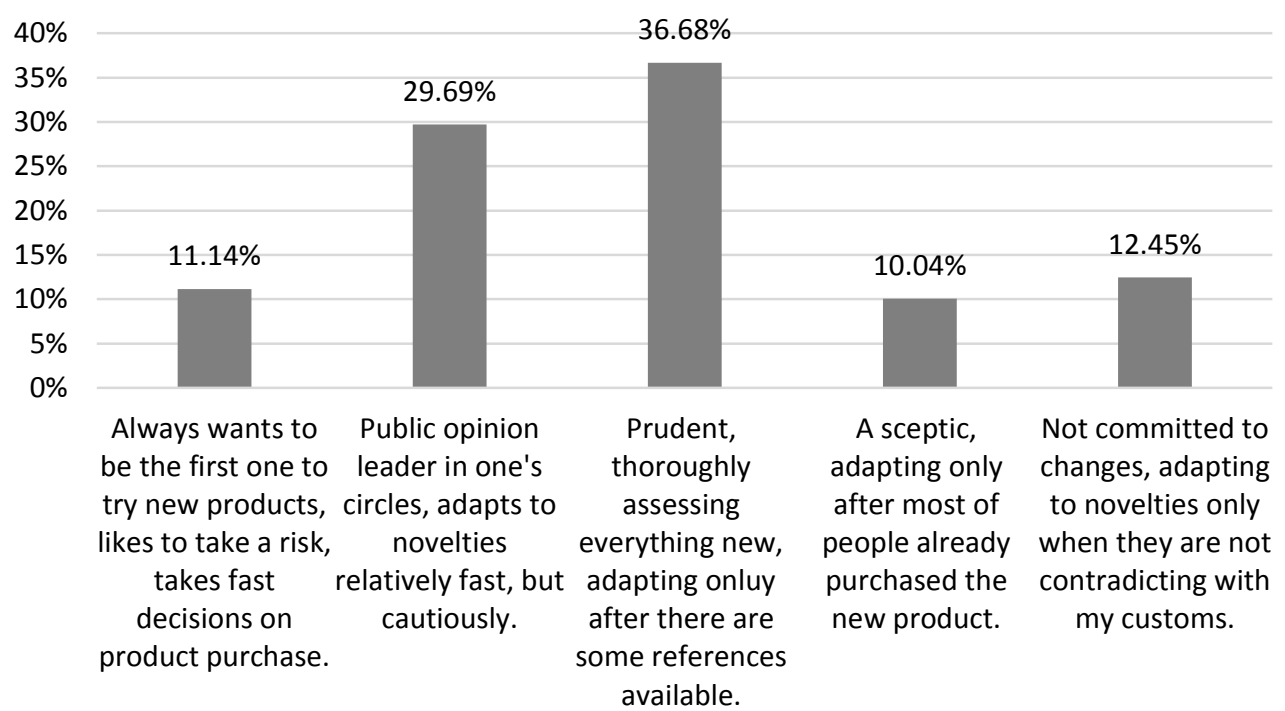

Figure 1 - Characteristics of respondents by their adaptation to innovative products (composed by the authors based on the results of the survey conducted) 
As a result of the study, the correlation between the level of income of respondents and the type of consumer in relation to innovations was revealed (see Table 1):

Table 1 - Correlation between the level of income of respondents and the type of consumer in relation to innovations (composed by the authors based on the results of the survey conducted)

\begin{tabular}{|c|c|c|c|c|c|c|}
\hline Income level & $\begin{array}{c}\text { Always } \\
\text { wants to be } \\
\text { the first one } \\
\text { to try new } \\
\text { products, } \\
\text { likes to take } \\
\text { a risk, takes } \\
\text { fast } \\
\text { decisions on } \\
\text { product } \\
\text { purchase. }\end{array}$ & $\begin{array}{c}\text { Public } \\
\text { opinion } \\
\text { leader in } \\
\text { one's } \\
\text { circles, } \\
\text { adapts to } \\
\text { novelties } \\
\text { relatively } \\
\text { fast, but } \\
\text { cautiously. }\end{array}$ & $\begin{array}{c}\text { Prudent, } \\
\text { thoroughly } \\
\text { assessing } \\
\text { everything } \\
\text { new, } \\
\text { adapting } \\
\text { onluy after } \\
\text { there are } \\
\text { some } \\
\text { references } \\
\text { available. }\end{array}$ & $\begin{array}{c}\text { A sceptic, } \\
\text { adapting } \\
\text { only after } \\
\text { most of } \\
\text { people } \\
\text { already } \\
\text { purchased } \\
\text { the new } \\
\text { product. }\end{array}$ & $\begin{array}{l}\text { Not } \\
\text { committed to } \\
\text { changes, } \\
\text { adapting to } \\
\text { novelties only } \\
\text { when they } \\
\text { are not } \\
\text { contradicting } \\
\text { with my } \\
\text { customs. }\end{array}$ & Total \\
\hline $\begin{array}{l}\text { Below } \\
\text { minimum } \\
\text { wage }\end{array}$ & $8.25 \%$ & $21.65 \%$ & $34.02 \%$ & $13.40 \%$ & $22.68 \%$ & $100.00 \%$ \\
\hline $\begin{array}{l}\text { Miimum wage } \\
\text { (430 EUR) }\end{array}$ & $11.27 \%$ & $22.54 \%$ & $40.85 \%$ & $8.45 \%$ & $16.90 \%$ & $100.00 \%$ \\
\hline $\begin{array}{l}\text { Between } \\
\text { minimum and } \\
\text { average } \\
\text { wage }\end{array}$ & $10.43 \%$ & $31.30 \%$ & $38.26 \%$ & $8.70 \%$ & $11.30 \%$ & $100.00 \%$ \\
\hline $\begin{array}{l}\text { Average } \\
\text { wage }(926 \\
\text { EUR [7]) }\end{array}$ & $10.64 \%$ & $36.17 \%$ & $32.98 \%$ & $12.77 \%$ & $7.45 \%$ & $100.00 \%$ \\
\hline $\begin{array}{l}\text { Above } \\
\text { average } \\
\text { wage }\end{array}$ & $14.67 \%$ & $36.00 \%$ & $40.00 \%$ & $5.33 \%$ & $4.00 \%$ & $100.00 \%$ \\
\hline High & $33.33 \%$ & $33.33 \%$ & $16.67 \%$ & $16.67 \%$ & $0.00 \%$ & $100.00 \%$ \\
\hline
\end{tabular}

The results show that the major part or $34.02 \%$ of respondents with income below the minimum wage consider themselves to be prudent people, or those who carefully assess everything new and adapt only when there are some references already. $22.68 \%$ of respondents with income level below the minimum wage consider themselves to be slowly adapting, or those who are not committed to changes and adapt to innovations only apply if the latter are not in contradiction with their customs. $21.65 \%$ of respondents with income level below the minimum consider themselves to be quickly adapting, that is, those who adapt to innovation quickly but with caution. $13.40 \%$ of respondents with a lower income level perceive themselves as late adapting or those who adapt to innovations only after most people have already purchased the new product, while $8.25 \%$ of respondents perceive themselves as innovators or those who always want to be the first to try out new products. The respondents whose income level is in the amount of minimum wage, in most cases, or $40.85 \%$ of cases, have stated that they perceive themselves as prudent, $22.54 \%$ are quickly adapting, $16.90 \%$ - slowly adaptive, and $11.27 \%$ - innovators, but the smallest part or $8.45 \%$ of respondents at this income level have indicated that they perceive themselves as late adapting. The majority of respondents, or $38.26 \%$, whose income level is among the minimum and average salary, have indicated that they perceive themselves as prudent purchasers in the field of innovations in packaged food and soft drinks, $31.30 \%$ - quickly adapting, $11.30 \%$ - slowly adaptive, $10.43 \%$ - innovators, but most respondents perceive themselves as late adapting. Most respondents, or $36.17 \%$, 
whose income is at the average wage level, consider themselves to be quickly adapting, $32.90 \%$ are prudent, $12.77 \%$ are late adopting, and $10.64 \%$ are innovators, while the smallest part or $7.45 \%$ of respondents considered themselves to be late adapting. Most of the respondents whose income is above the average wage level, or $40.00 \%$ admitted that they are prudent in the field of packaged food and nonalcoholic beverages, $36.00 \%$ are rapidly adapting, $14.67 \%$ are innovators, $5.33 \%$ are late adapting, but the smallest portion of respondents, or $4.00 \%$, admitted that they are slowly adapting. The respondents with a high income level, in most cases, or $33.33 \%$ of cases, recognize themselves as innovators, and an equally large proportion of respondents admit themselves to be quickly adapting. $16.67 \%$ of respondents feel that they are prudent, but still as many consider that they are late adapting.

Consequently, it can be concluded that in most of cases regardless of the level of income, Latvian residents perceive themselves as prudent people who carefully assess innovations, and adapt only according to the public opinion leaders. At the same time, however, there is a tendency - the higher the income level is, the higher is the number of people who perceive themselves as innovators or quickly adapting in the field of packaged food and non-alcoholic beverages, and the lower the income level is, the greater is the number of slowly adapting people.

The authors have analyzed which consumer type is mostly chosen by each gender. It has been found that males mostly marked (32\%) that they are public opinion leaders in their circles and adapt to innovations fast enough but with caution. Most females (41\%) have noted that they are cautious; they carefully assess everything new and adapt only after they have already had some references. (see Table 2):

Table 2 - Consumer type breakdown by gender (composed by the authors based on the results of the survey conducted)

\begin{tabular}{|l|c|c|}
\hline Consumer types & Males & Females \\
\hline Innovators & $16 \%$ & $8 \%$ \\
\hline Quickly adapting & $32 \%$ & $28 \%$ \\
\hline Prudent & $30 \%$ & $41 \%$ \\
\hline Late adapting & $13 \%$ & $8 \%$ \\
\hline Slowly adapting & $9 \%$ & $15 \%$ \\
\hline
\end{tabular}

It can be observed that $15 \%$ of females, compared to $9 \%$ of males, are not committed to changes and adapt only if these do not contradict with their customs.

Hence, males would more often buy innovative products, try new ones and take risks, while females would be more cautious and would assess carefully everything new, possibly after they have heard some positive references.

Considering what consumer types are the most widespread in different age groups, it can be observed that in the 18-27 years old age group the largest portion or $43.4 \%$ are prudent and $29.3 \%$ are quickly adapting people. In the age group of 28-37 years old, the largest part or $50 \%$ are quickly adapting while $31.9 \%$ of the respondents are prudent. In the age group of $38-47$ years old the largest portion or $34.2 \%$ are quickly adapting and $25 \%$ of respondents are prudent. In the age group of $48-57$ years old the largest portion of respondents or $42.6 \%$ are prudent and $22.1 \%$ of respondents are fast adapting. In the age group of 58-67 years old, the largest part of respondents or $37.1 \%$ are prudent and $32.3 \%$ of respondents are quickly adapting. In the last age group of above 67 years old $39.3 \%$ of respondents are prudent and $27.4 \%$ of respondents are slowly adapting. Based on the aforementioned, it can be concluded that the proportion of innovators as a whole decreases as age grows, and for quickly adapting ones the tendency is even faster. The proportion of prudent ones in groups up to the age of 47 years decreases; however, afterwards, with the age growing, it increases and stabilizes. The proportion of late adapting people increases with 
age and so is the portion of slowly adapting people.

Overall, the largest part or $42.58 \%$ of respondents acknowledged that they were positively value innovations in packaged food and non-alcoholic beverages industry; $30.13 \%$ of respondents evaluate innovations in this field rather positively. Innovations in food and non-alcoholic beverages industry have been assessed neutrally by $21.83 \%$ of respondents, assessed rather negatively by $3.71 \%$ and negatively - by $1.75 \%$ of respondents (see Figure 2). Generally, respondents' attitude towards innovations in packaged food and non-alcoholic beverages industry is positive, which means that Latvian residents are open and ready to accept innovative solutions for packaged food and non-alcoholic beverages. There is no significant difference in attitude towards innovations in packaged food and non-alcoholic beverage industry for males and females.

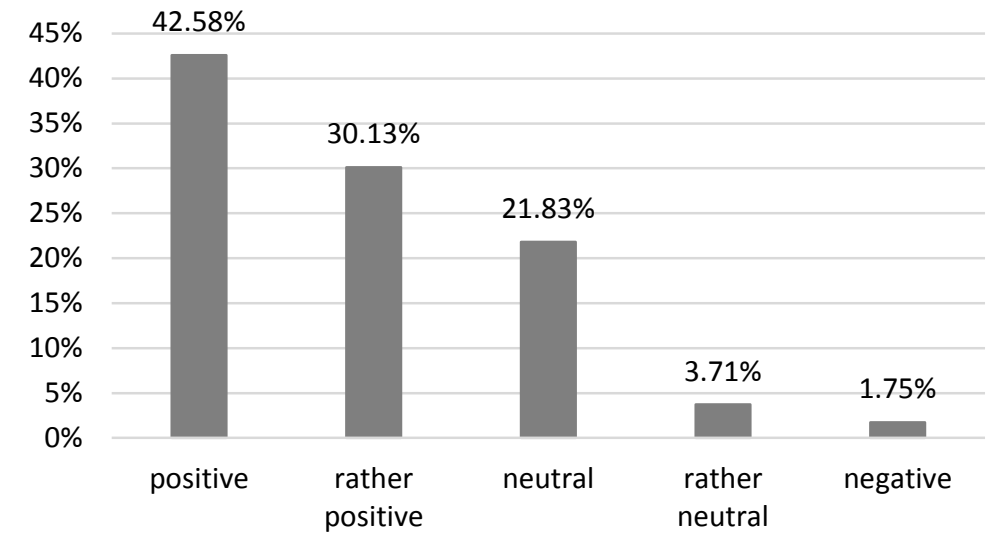

Figure 2 - Respondents' attitude towards innovations in packaged food and non-alcoholic beverages industry (composed by the authors based on the results of the survey conducted)

According to the results of the research, it has been found that respondents receive information on novelties of packaged food and non-alcoholic beverages through various distribution channels, but the most popular distribution channel among the respondents is TV, and this answer option is noted in $25.44 \%$ cases. Almost as many, or $24.47 \%$, respondents noted that this type of information is obtained from Internet. The third most popular distribution channel among the respondents was friends and acquaintances, noted in $19.65 \%$ of cases. $12.28 \%$ of all replies indicated that the information was obtained from newspapers and magazines, $11.75 \%$ of all responses marked that it was the environment, $5.61 \%$ of respondents noted that the information is received by radio, while the answer "Cinema" was chosen only in $0.79 \%$ of all responses (see Figure 3 ).

From the data obtained, it can be concluded that among the respondents in general, information on packaged food and non-alcoholic beverages is mainly obtained through TV and Internet, as well as from friends and acquaintances.

One can observe a correlation - the older a person is, the more often the information on innovations in packaged food and non-alcoholic beverages is obtained through TV, the same is for newspapers and magazines, but the situation with Internet is just the opposite: the younger a person is, the more often information about novelties in packaged food and non-alcoholic beverages is received through Internet. 


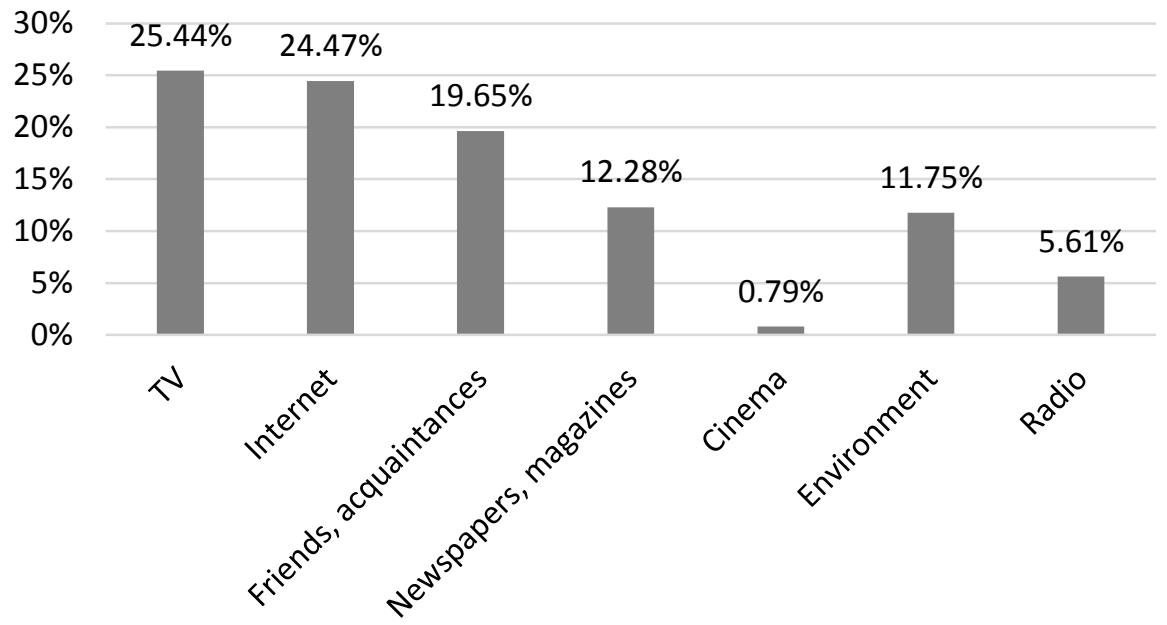

Figure 3 - Distribution channels the respondents get information on packaged food and nonalcoholic beverages novelties from (composed by the authors based on the results of the survey conducted)

The largest portion of respondents, or $18.98 \%$, reveal that they generally understand that the product of packaged food or non-alcoholic beverages is innovative when there is an appropriate advertising. $18.08 \%$ of all responses indicated that the respondent understands that the product is innovative when an indication on the shelf is provided, in $16.92 \%$ of all submitted responses it was indicated that the respondent understands that the product is innovative when it is written on the packaging, $14.15 \%$ - when the company itself tells about the new features of the product, $13.70 \%$ - when the product offers new functions, $11.82 \%$ - provided that it was explained to the respondent by relatives/ friends/colleagues, $5.73 \%$ - provided that there is previous knowledge, but $0.63 \%$ - other. So, the most common ways for a respondent to understand that a packaged food or non-alcoholic beverage product is innovative is when there is an appropriate advertising, when there is an indication on the shelf is provided or when it is written on the package.

It should be noted that in the age group of 18-57 years old, the most important feature by which the consumers can determine that the product is innovative is an appropriate advertising, but starting from the age of 58, if there is an indication on the shelf. In case the information is written on the package, there is an indication on the shelf and relatives/friends/colleagues provide explanations, the age group of 67 years and above will be reached most likely. Providing new functions of the product and telling about the new opportunities by the company itself will address the youngest audience - from 18-27 years old, an appropriate advertising - the age group of 38-47 years old, while prior knowledge is a decisive factor for the age group of 28-37 years old.

Carrying out analysis by types of consumers, the authors have found the following: the more people are open to new things and the quicker they adapt, the less incentives are required to persuade the consumers to buy an innovative product. For those who adapt slowly, all marketing activities are not enough; the suggestions of people around are needed so get them ready to buy something innovative, as they strive for proven and known values.

As a result of the research, the factors, based on which the respondents chose to try out innovative packaged food and non-alcoholic beverages have been identified. Most respondents choose to try these innovative products because they have been recommended by their friends, relatives or acquaintances - 
this answer makes $16.53 \%$ of all responses provided. $14.48 \%$ of all responses is the answer "Discount", which means that a large proportion of respondents choose to try new products because they have a discount. $14.08 \%$ of all responses provided suggest that it is important for the respondents that the new product is more comfortable to use, $13.61 \%$ of all responses provided indicate that people choose to try innovative products when a popular brand starts trading a new product, $11.55 \%$ of all responses provided indicate that respondents choose new products because of an appropriate advertising and other marketing communications, $10.84 \%$ of all replies indicated that the respondents choose new products because they always want to try something new, $9.81 \%$ of all responses provided indicate that the respondents choose new products because the new product has an attractive design, $8.54 \%$ of all responses provided indicate that respondents prefer innovative products because they are in line with their lifestyle trends, but $0.55 \%$ of all responses provided have chosen "Other" reply option (see Figure 4).

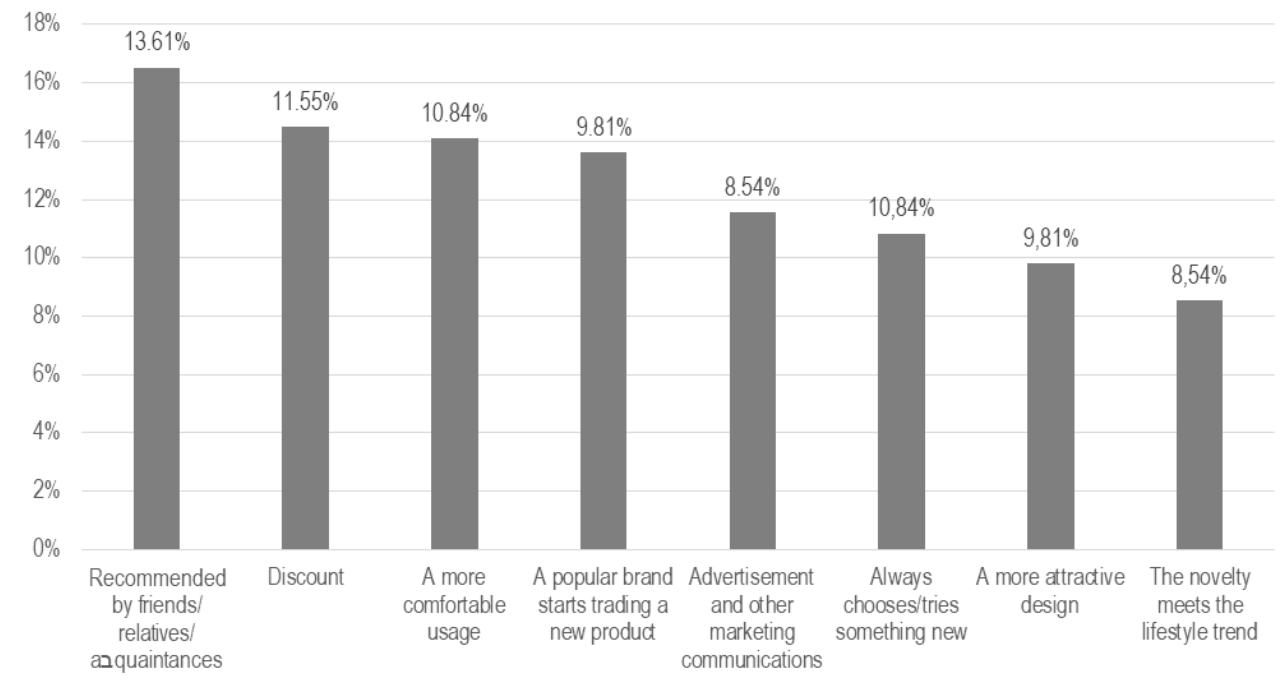

Figure 4 - Factors that make the respondents choose an innovative packaged food and nonalcoholic beverage product (composed by the authors based on the results of the survey conducted)

Based on the results of the research, it can be concluded that as age grows, the desire to choose and try something new decreases. In the age group of 18-27 years old, the key factors are to choose and try out something new as well as a more attractive design. The respondents aged 38-47 years old mention advertising and other marketing communications as the most important factor in attracting attention to the selection of innovative products. The respondents aged above 48 mention discounts as one of the three most important factors for the purchase of innovative products. Starting from the age of 58 , it is no longer essential for the respondents to choose something new, as well as whether the novelties are in line with the lifestyle trends, or whether the product has an appropriate advertisement and other marketing communications; for this age group it is important that the product has a discount and is recommended by a friend or an acquaintance. It can be concluded that in the age group of over 67 years old, the desire to buy innovative products decreases, unless a relative recommends it, the product has a discount or the new product is more comfortable to use.

As the result of the research, the importance of specific factors for innovative packaged food and nonalcoholic beverage products has been revealed. The respondents needed to assess each factor based on 5 -point scale ( 1 point is for the answer option "minor", and 5 points, respectively, for the option "important"). 
Subsequently, average arithmetic estimates were calculated. According to the results obtained, it can be concluded that the most important factor for an innovative product, according to respondents, is the price; this answer option has got 4,48 points. This means that the most important issue for the respondents is to have a good, affordable price for the new product. The answer option "easy to use" follows with 4.3 points, which means that it is important for the respondent that the innovative product is easy to use. The third most important factor with 4.09 points is the "product used on a daily basis" response, which means that it is important for the respondents that the particular innovative product is something that the respondent uses on a daily basis. It is quite important for the respondents that the innovative product is produced by a popular and reliable brand, as this answer option has got 3.93 points. The answer option "visually attractive product and/or packaging design" got 3.75 points follow by the option "the product and/or product packaging is ecologically sound" with its 3.46 points, while appropriate advertising and marketing communication factor was scored 3.23 while being in line with modern trends was scored 3.19 points. In turn, the least important factor, according to the respondents, is the fact that many innovative products are used by many people; this answer has got only 2.94 points (see Figure 5).

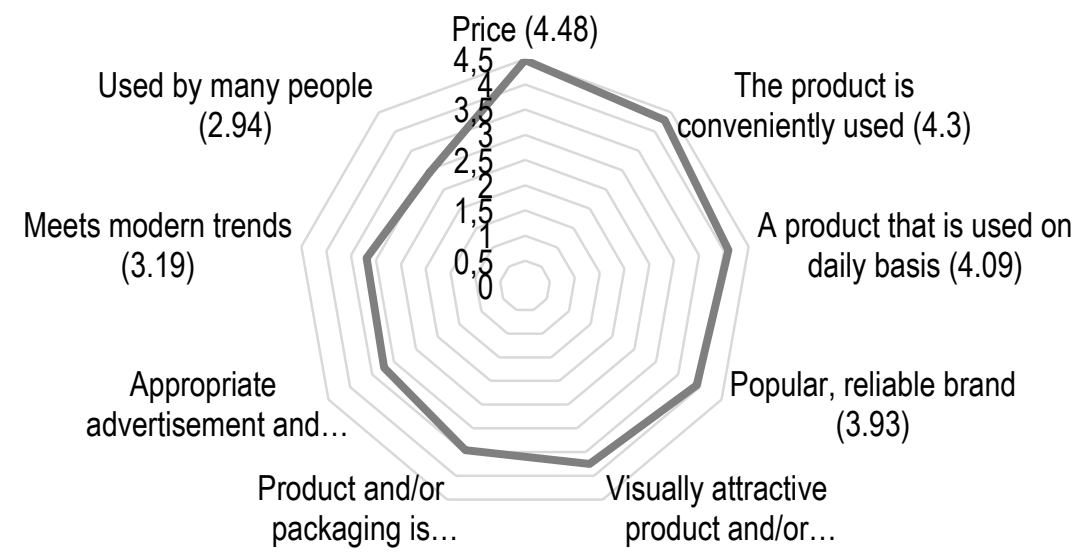

Figure 5 - The importance of factors for packaged food and non-alcoholic beverage product (composed by the authors based on the results of the survey conducted)

The largest part of respondents, or $21.20 \%$, have indicated that they expect from innovative/new packaged food and non-alcoholic beverage products the most to be healthier, $19.06 \%$ expect a tastier product, $16.35 \%$ expect a more comfortable use, $15.92 \%$ - new flavors, $11.56 \%$ expect a more natural product (eco, bio), $10.06 \%$ - a more ecologically sound packaging, and $0.14 \%$ of respondents have marked the answer "Other". Overall, it can be concluded that it is important for respondents that the new packaged food and non-alcoholic beverage products are healthier and tastier, that manufacturers should focus more 
on creating new flavors and receipts. Females are more concerned about their health and thus try to choose healthier and more natural products, but males are more likely to expect a tastier product and new flavors.

The biggest group of respondents, or $37.12 \%$, responded that the chance of purchasing an innovative packaged food or non-alcoholic beverage is the greatest during unplanned shopping. $31.66 \%$ of respondents acknowledged that the highest probability to buy innovative products is the highest during the weekend shopping, while $27.95 \%$ of respondents admitted that they are most likely to be bought during daily purchasing. A very small part of respondents, or $2.84 \%$, believe that the probability to buy this type of innovative product is the greatest in internet shops, while $0.44 \%$ of respondents marked the answer "Other". Further examining the issue when the respondent would pay attention and buy an innovative food or non-alcoholic beverage, by gender, it can be observed that males tend to buy innovative products at weekends in $38 \%$ of cases while for $39 \%$ of females these were unplanned purchases.

Gender also affects the quantity of innovative packaged food and non-alcoholic beverages purchased. Males are mostly those who buy more than 3 products, while females mostly buy no products or 1-3 products per month, which is probably because males are more likely to experiment more and try out something new as well as used to have higher earnings, while females are more prudent and choose more reliable and popular products and brands.

Conclusions. As the result of the study of the factors, influencing the behavior of Latvian consumers in purchasing innovative packaged food and non-alcoholic beverage products, it can be concluded that consumer adaptation process for innovative products in this product category depends on age, gender and income levels. The higher income level is, the higher is the proportion of people who perceive themselves as innovators or quickly adapting in the filed of packaged food and non-alcoholic beverages, and the lower income level is, the greater is the proportion of slowly adapting people.

Males would purchase innovative product, try something new and take risks more often while females would be more prudent and assess everything new more thoroughly, probably only after they have heard some positive reviews. The frequency of purchases of innovative products is higher for males than for females. The share of innovators, as a whole, decreases with age; the tendency observed for quickly adapting ones is even more dramatic. The portion of late adapting and slowly adapting people increases with age. Females are more concerned about their health and they try to choose healthier and more natural products, while males are more likely to expect a better taste and new flavours. This fact should be considered when developing the content of marketing communications for innovative products. Due to the fact that for the respondents under the age of $67 \mathrm{TV}$, Internet and friends or acquaintances are the most popular distribution channels they receive information on novelties in packaged food and non-alcoholic beverages from, companies need to implement an integrated approach to the selection of marketing communication distribution tools, planning communication with innovative product target audience.

In general, the specificity of packaged food and non-alcoholic beverages is explained with the fact that consumers adapt to innovative products of this category much faster because it does not require large investments. Among further directions of study of consumer behaviour in purchasing innovative products, the research of different consumer groups, depending on the adaptation to a new product, values and lifestyle in order to improve the marketing activities of innovative businesses as well as the factors, influencing repeated purchases of innovative products and the efficiency of innovation products sales promotion methods can be named.

1. Ahlstrom, D. Innovation and Growth: How Business Contributes to Society, Academy of Management Perspectivs, 2010, Vol. 24, pp. 11-24. 135

2. Antonelli, C. The Economics of Innovation, New Technologies, and Structural Change, Routledge, London, 2003, pp. 89- 
3. Axtell, C.M., Holman, D.J., Unsworth, K.L. Wall, T.D., Waterson, P.E., Harrington, E. Shopfloor innovation: facilititating the suggestion and implementation of ideas, Journal of Occupational and Organizational Psychology, Vol. 73, 2000, pp. 265-285.

4. Batraga, A., Salkovska, J., Braslina, L., Legzdina, A., Kalkis, H. (2019) New Innovation Identification Approach Development Matrix. In: Kantola J., Nazir S., Barath T. (eds) Advances in Human Factors, Business Management and Society. AHFE 2018. Advances in Intelligent Systems and Computing, vol 783. Springer, Cham.

5. Bessant, J., Lamming, R., Noke, H., Phillips, W.Managing innovation beyond the steady state, Technovation, Vol. 25, No. 12, 2005, pp. 1366-1376.

6. Brown, S., Eisenhardt, K. Product development: Past research, present findings, and future directions. Academy of Management Review, Vol. 20, No.2, 1995, pp. 343-378.

7. CSP majas lapas datubazes. Retrived from https://www.csb.gov.lv/lv/statistika/db

8. Damanpour, F., Schneider, M.Phases of the adoption of innovation in organizations: effects of environment, organization and top managers, British Journal of Management, Vol. 17, No.3, 2006, pp. 215-236.

9. Dosi, G. Finance, innovation and industrial change, Journal of Economic Behaviour\&Organization, Vol. 13, No.3, 1990, pp. 299-319.

10. Dubra, I. Inovacijas Baltijas valstis un to ietekmejosie faktori. 2014, (Doctoral dissertation).

11. Dubra, I. The Evaluation of Influential Factors on Enterprises Innovation Capacity in Latvia, 7th International Forum on Knowledge Asset Dynamics. 5th Knowledge Cities World Summit, Knowledge, Innovation and Sustainability: integration micro and macro perspectives Proceedings e-book, 2012, pp. 264-279.

12. Eisenhardt K., Tabrizi N. Accelerating adaptive processes: product innovation in the global computer industry, Administrative Science Quarterly, Vol. 40, No.1, 1995, pp. 84-107.

13. Ettlie, J.E., Reza, E.M. Organizational integration and process innovation, Academy Management Journal, Vol. 35 , No. 4 1992, pp. 795-827.

14. Kimberly, J.R. Managerial innovation, in Nystrom, P.C. and Starbuck, W.H. (eds), Hand book of Organization Design, Oxford university Press, Oxford, 1981, pp. 121-139.

15. Nielsen, "Nielsen Breakthrough Innovation Report - European Edition". 2014 Retrived from https://studylib.net/doc/8158985/nielsen-breakthrough-innovation-report

16. Nonaka, I. A dynamic theory of organizational knowledge creation, Organization Science, Vol. 5, No.1, 1994, pp. 14-37.

17. OECD, Economic survey of the European Union 2007: Key challenges for the European Union. Retrived from htpp://www.oecd.org/eco/49950244.pdf.

18. Olevskis, G., Dunska, M. Knowledge - the Intellectual Capital - Enterprise Activity: Interrelation and Interconditionaly. International Scientific Conference „Contemporary Issues in Business, Management and Education'2012”, Conference Proceedings, ISSN 2029-7963/ISBN 978-609-457-323-1, Vilnius Gediminas Technical University, Lithuania, 2012, pp. 407-417.

19. Olevskis, G., Dunska, M. Preconditions for the Internationalization of Knowledge-Intensive Entrepreneurship, Humanities and Social Sciences. Latvia, Vol.23, N 2, 2015, pp. 71-85.

20. Pfeiffer, F., Brade, J. Weiterbildung, Arbeitszeit und Lohneinkommen, in: Steiner, V. Bellmann, L. Mikrookonomik des Arbeitsmarktes, Beitrage zur Arbeitsmarkt und Berufsforschung 1995, pp. 289-326.

21. Plessis, M.D. The role of knowledge management in innovation, Journal of Knowledge Management, Vol. 11, No. 4, 2007, pp. 20-29.

22. Praude, V., Salkovska, J. Integreta marketinga komunikacija: 1.dala. Riga: Burtene, 2015., pp.464.

23. Rodriguezi, A. Dahlman, C., Salmi, J. Knowledge and innovation for competitiveness in Brasil, Globalization, Competitiveness \&Governability, Vol. 2, No.3, 2008.

24. Salkovska, J., Batraga, A., Zilina, B. Digital Marketing as Innovative Marketing Technology. New Challenges of Economic and Business Development - 2017: Digital Economy: International Scientific Conference, May 18-20, 2017, Riga, Latvia: Proceedings of Reports Riga: University of Latvia, 2017, pp.543-552. Retrived from https://dspace.lu.Iv/dspace/handle/7/37260ISBN 9789934182860 .

25. Schumpeter, J.A. Capitalism, Socialism and Democracy, Harper \& Row, New York, 1950.

26. Thompson, V.A. Bureaucracy and innovation, Administrative Science Quarterly, Vol. 10, 1965, pp. 1-20.

27. Tidd, J., Bessant, J., Pavitt, K. Managing Innovation. Integrating Technological, Market and Organizational Change. (3rd edition). New York; wWiley, 2005, pp. 120-159.

28. Tirole, J. "The Theory of Industrial Organization." MIT Press, Cambridge, 1988. 607.

29. Van de Ven, A. Central problems in the management of innovation, Management science, Vol. 32, No. 5, 1986, pp. 590

30. Zahra, S.A., Covin J.G. The financial implications of fit between competitive strategy and innovation types ans sources, The Journal of High Technology Management Research, Vol. 5, No. 2, 1994, pp. 183-211.

31. XTC World Innovation, World Innovation Panorama. Key facts, new trends, outstanding concepts in food innovation. 2015. 
М. Дунска, д.е.н, професор, Латвійський університет (Рига, Латвія);

Е. Шалковска, д.е.н, асистент, Латвійський університет (Рига, Латвія);

А. Батрага, д.е.н, професор, Латвійський університет (Рига, Латвія);

Л. Браслиня, науковий співробітник, Латвійський університет (Рига, Латвія).

Поведінка споживачів у процесі придбання інноваційних товарів

На сучасному етапі функціонування світової економіки інновації стали індикатором успішності підприємнццької діяльності як передумови ефективного розвитку національної економіки. На основі вивчення теорії поведінки споживачів автори аналізують фактори впливу на поведінку латвійських споживачів при купівлі інноваційно упакованих продуктів харчування та безалкогольних напоїв. В результаті дослідження авторами розроблено рекомендації латвійським компаніям щодо вдосконалення діяльності з маркетингу інноваційних товарів, їх комерціалізації і просування на ринку. Дослідження проводилось на основі структурованих даних, отриманих у ході опитування 458 латвійських респондентів (структура вибірки: 59,65\% жінок та 40,35\% чоловіків). Усі респонденти були розділені на шість вікових груп, починаючи з 18 років, вікова група молодше 18 років не бралась до уваги, оскільки представники цієї групи не мають особистих доходів для придбання продуктів харчування та безалкогольних напоїв. У відповідності до отриманих результатів автори виокремлюють основні специфічні характеристики респондентів за рівнем їх ставлення до інноваційних товарів, розділяючи їх на: «інноваторів», «послідовників» та тих, що «повільно адаптуються». 3 метою оцінки взаємозв'язку між рівнем доходів, віком, гендерною ознакою респондентів та рівнем їх ставлення до інноваційних товарів, автори використовували кореляційний аналіз. Отримані результати свідчать про позитивну кореляцію між рівнем доходів та ставленням споживачів до інноваційних товарів. Так, в групі «інноваторів» частка осіб з високим рівнем доходу була найбільшою, у групі «послідовників» - середньою, у групі споживачів, які «повільно адаптуються» - найнижчою. Автори наголошують, що в цілому для ринку продуктів харчування та безалкогольних напоїв характерна швидка адаптація споживачів до інноваційної упаковки, пояснюючи це низькими витратами на впровадження інновацій у порівнянні з іншими видами товарів.

Ключові слова: поведінка споживачів, інноваційний продукт, інноваційна упаковка, адаптація до інновацій, інновації. 